\title{
A Preliminary Study on the Method of Mencius 'Argumentation - From the Perspective of Pragma-Dialectics
}

\author{
Yang Zhaofu* \\ School of Philosophy, Beijing Normal University, 19 Xinjiekouwai Street, Beijing, 100875, China \\ *Corresponding Author: Yang Zhaofu, School of Philosophy, Beijing Normal University, 19 \\ Xinjiekouwai Street, Beijing, 100875, China
}

\begin{abstract}
Mencius, who lived in the warring States period where a hundred schools of thought competed against each other, was famous for his "being good at argumentation". In order to carry out his thought of "benevolence", he argued with the kings of various kingdoms. This paper draws lessons from the method of the School of Pragma-Dialectics which evaluates natural language argumentation, picks up several fragments of Mencius' argumentation, and tries to explore Mencius' argumentative practice from three dimensions, that is, logic, dialectics and rhetoric. It can be seen that Mencius attached great importance to logical methods, mastered argumentative strategies, used rhetorical skills skillfully, looked at the development of things dialectically, implemented strategic maneuvering and achieved a rational balance between logical rationality, argumentative reasonableness and rhetorical validity, accessing the Dao of argumentation.
\end{abstract}

Keywords: Mencius; Dialectical Reasonableness; Rhetoric Effectiveness; the Dao of Mencius' Argumentation

\section{INTRODUCTION}

Liu Xie, a master who studied ancient literary criticism (about 465-520 years), wrote in The Literary Mind and the Carving of Dragons: "the argument of one word is more important than the treasure of nine tripods; the tongue of three inches is better than the teacher of millions." It can be seen that his evaluation of the argumentation has reached an unprecedented height. Mencius, who lived in the middle of the warring States period, one of the representatives of Confucianism after Confucius, is known as "sub-saint" and is famous for his eloquent eloquence. Mencius' argument, from small to big, from shallow to deep, with strict logic, has great persuasive power to insist on his own point of view, and impregnable defense power to refute the other side's point of view. Although Mencius himself once mocked himself, "Do I really like to argue? I had to do it." However, judging from the specific argumentation embodied in Mencius, it is clear that Mencius is too modest. Instead of being argumentative, Mencius is good at argumentation.

One of the reasons why Mencius was "argumentative" was his admiration for Confucius himself and his thought. Unlike Mozi ${ }^{1}$, Mencius was not an argumentative theorist, but a well-known argumentation practitioner, and did not form his own systematic argumentation theory, but his argumentation practice has greatly inspired later Chinese scholars to develop argumentation theory. Living in the middle of the Warring States period, the thoughts of Confucian school showed signs of a crisis of faith. Mencius regarded Confucius as the first of the three saints, strongly respected Confucius' thought of "benevolence", tried to inherit and carry forward Confucius' thought, and lamented that "If the theory of Yang Zhu and Mozhai did not perish, the theory of Confucius would not be great" ("Mencius - Teng Wen Gong Xia"),so Mencius was determined to "correct the hearts of the people, get rid of heresies, resist biased behavior, refute erroneous and exaggerated remarks" (ibid.), and bluntly said, "Anyone who could write books and dared to boycott Yang and Mohism are worthy of being students of saints. " Secondly, another reason why Mencius was argumentative is that he, like Confucius, had a strong sense of social responsibility. He put forward the thought of benevolence policy on the basis of Confucius' theory of human nature. In addition, he devoted his life to persuading his

\footnotetext{
${ }^{1}$ Mozi (about 468 BC-376 BC), also known as Mo Di, was the founder of Mohism, a famous thinker, educator, scientist, strategist, argumentative theorist (and even logician) during the warring States period.
} 
target audience, King Liang Huiwang, King Qi Xuanwang and Duke Teng Wen, to accept his basic political stand on humanitarian policy and advocate humane governance, that is, the policy of benevolence, so that the rulers became the real monarch, common people lived and worked in peace and contentment.

The pragma-dialectical theory of argumentation ${ }^{2}$ was founded by Frans van Eemeren and Rob Grootendorst (1944-2000) at the University of Amsterdam in the 1970s and developed in the next 40 years. Consistently, the argument in this theory is regarded as a communicative perspective inspired by pragmatic insights in speech act theory and discourse analysis, and a critical perspective inspired by argumentative insights in critical rationalism and formal dialectics. As people use argumentation in all aspects of life to convince others of their views on beliefs, ideas or actions, Frans van Eemeren and Rob Grootendorst believe that it is essential to create an adequate theoretical basis for improving their analysis, evaluation and production. The overall planning of their development of this theoretical basis is to gradually develop from an abstract argumentation ideal model to the concrete reality of all kinds of argumentation practice.

Learning from the method of the Pragma-Dialectics to evaluate the natural language argumentation, this paper attempts to explore Mencius' argumentative practice from two dimensions, namely, the dialectical dimension ${ }^{3}$ and the rhetorical dimension. From the perspective of Dialectics, in the process of arguing with princes such as King Xuan of Qi, and with disciples and other scholars who held dissenting views, Mencius, based on the premise of argumentation shared by both parties, persuaded the other party to accept his own standpoint with the help of critical speech acts to eliminate differences of opinion between each other. From the perspective of rhetoric, it is necessary to fully take into account the context of the argumentation and its changes, the choice of the topic, the ingenious and appropriate use of the means of presentation, and take the quality of persuading the target audience as the key sign to measure the effectiveness of the arguing. Besides, the dimension of logic is included in the dialectical dimension and must be considered in any argumentative practice, and is the rational cornerstone of any argumentative practice.

\section{Dialectical REasonableness}

The School of Pragma-Dialectics, led by the Amsterdam school founded by van Eemeren, considers a pragmatic dimension ${ }^{4}$ when evaluating arguments, that is, in addition to the speaker, the receiver and the content of the discourse, there is also an important element of context ${ }^{5}$ to be considered in the process of argumentation. Context refers to the environment in which language is used, that is, the environment in which speech act occur. According to the standard theory of Pragma-Dialectics, argumentation should go through the confrontation stage, the opening stage, the argumentation stage and the conclusion stage, and formulate ten critical discussion rules ${ }^{6}$ (also called "Ten

\footnotetext{
${ }^{2}$ vanEemeren F.H., Garssen B., Krabbe E.C.W., et al. Handbook of Argumentation Theory[M]. Berlin: Springer Netherlands, 2014, pp.523-524..

${ }^{3}$ In pragma-dialectics, a kind of discourse which wants to be dialectical needs to have some qualities, and at least meets four conditions: involves points of different opinions, systematic methodology of resolution (dialogue, arguments, critique, and appropriate response to the criticism), regulated discussion processand related reasonable standards. Therefore, the dialectical dimensionen bodies the most basic logical requirements for social activities, such as following logical rules, i.e., the law of Identity, non-contradiction, excluded middle add sufficient evidence.

${ }^{4}$ XiongMinghui. Logical Analysis of Natural Language Argumentation and Evaluation. Philosophical Studies, No. 10, 2006, pp. 102-108.

${ }^{5}$ According to van Eemeren, the generation, understanding and evaluation of argumentative discourse should be restricted by four contextual factors: micro context (context), meso context (immediate situation), macro context (institutional constraint) and intertextual context. See Wu Peng, XiongMinghui. Strategic Maneuvering: a Rhetorical Extension of Pragma-Dialectics. Journal of Fujian normal University (Philosophy and Social Sciences Edition), No. 3, 2015, pp. 64-69.

${ }^{6}$ In order to standardize the model of critical discussion, Pragma-Dialectics has formulated ten rules, also known as the Ten Commandments of argumentation, among which are The Freedom Rule, The Burden of Proof Rule, The Standpoint Rule, The Relevance Rule, The Unexpressed Premise Rule, The Argumentation Scheme Rule, The Validity Rule, The Conclusion Rule and The Usage of Language Rule, respectively. According to the theory of Pragma-Dialectics, any party who violates one or more of the rules in the process of argumentation is considered to have committed fallacy. These pragmatic criteria make it possible to evaluate argumentation. Seevan EemerenF.H., R. Grootendorst, A. F. SHenkemans: Argumentation: Analysis, Evaluation, Presentation [M]. Mahwah: Lawrence Erlbaum Associates, 2002, pp.82-183.
} 
commandments") for argumentation. In the confrontation stage, the two parties have different views on the same issue, and its argumentative goal is to clarify the specific issue in the dilemma of differences of opinion and the roles that both sides should assume in the argumentation; The opening stage aims at establishing a clear starting point for the discussion, which is made up of inter subjectively acceptable procedural and substantive starting points-mutual concessions, and also includes agreement on the distribution of the burden of proof; In the argumentation stage, setting up from the starting points established in the opening stage, the goal is to test the feasibility of the standpoint which forms differences of opinion in the confrontation stage. In the conclusion stage, the goal of both sides is to establish the results of the critical test procedure and decide whether protagonist would nevertheless maintain its own position, when challenged by antagonist, or whether antagonist still insists on casting doubt on protagonist's point of view after considering the argumentation made by protagonist to defend its standpoint.

If the parties involved violates one or more rules of discussion in the process of argumentation, the argumentation is then regarded as unreasonable and fallacious. These four stages correspond to the different stages that argumentative discourse must go through, and the two sides resolve their differences of opinion on the merits ${ }^{7}$.In the following piece of argumentation, Mencius adheres to principles and can be flexible, not stubborn, considers the different contexts, makes a concrete analysis of the specific problems, treats the problem at issue dialectically, and conducts critical exchanges with the other party of the argumentation facing the other party's questioning of his own views. Finally, the differences of opinion could be resolved so as to realize the dialectical reasonableness, which fully reflects Mencius's thought of dialectics.

Chunyukun asked, "is it a rule of etiquette that you don't pass anything between men and women?"

Mencius replied, 'yes.' Chunyukun then asked, "well, if your sister-in-law falls into the water, will your brother-in-law pull her with his hand?"Mencius said: "If the sister-in-law falls into the water, but the brother-in-law does not pull her, it is simply a jackal!" It is the rule of etiquette that men and women do not pass things with hands. When my sister-in-law falls into the water and my brother-inlaw pulls her with his hand, it is regarded as not sticking to the old way of doing things, and knows how to adapt to the circumstances.

Chunyukun said, "Now the whole world is under water. Sir, why don't you come to the rescue?"Mencius said: "the whole world falls into the water, and use the 'Tao' to rescue it while the sister-in-law falls into the water, and pull herwith the hands is just OK-do you want me to save the world with my hands?"(Mencius.Li Lou (part one)) ${ }^{8}$

Chunyu Kun opened the confrontation stage of argumentation with a rhetorical question. Mencius showed great wisdom in dealing with the tricky problem raised by Chunyu Kun. Mencius believed that "men and women were not allowed to be close to each other" was the etiquette regulation of the feudal society at that time, which is the principle, on the one hand; I saw my sister-in-law fall into the water in danger but did not lend a helping hand. Although it followed the rules of feudal etiquette, she deviated from the higher rule of "benevolence and righteousness". However, not being constrained by the shackles of feudal etiquette in the specific circumstance, that is, when the sister-in-law fell into the water, thus facing the danger of life, that a "specific circumstances, specific analysis" principle is adopted is flexibility, on the other hand. These were the prerequisites accepted by both sides, and based on these common ground, the argumentation entered the opening stage. Mencius dialectically unified principle and flexibility and asked rhetorically, "Do you want me to save the world with my hands?" It not only lambasted Chunyu Kun for distorting and understanding the anomie of feudal etiquette, but also naturally extended his lofty political ambition of pursuing benevolence and carrying out "kingship" to save the common people all over the world, thus entering the argumentation stage smoothly. Flexibility seems to deviate from the feudal etiquette of abiding by the principle, and even violated the basic requirements of the principle, but in fact, Mencius really abided by the moral principle of "benevolence and righteousness" here, reasonably completed the mission entrusted by the

${ }^{7}$ vanEemerenF. H.Argumentation Theory: A Pragma-Dialectical Perspective [M]. Berlin:Springer Netherlands, 2018, p.36..

${ }^{8}$ Yang Bojun. Mencius Translated Notes. Beijing: Zhonghua Book Company, 2010, p. 193. 
'principle', and finally realized the theoretical cornerstone of the goodness of human nature, which paved the way for persuading the monarch to carry out the policy of benevolence. Right at this time, the argumentation came to the conclusion stage.

In the process of argumentation, Mencius took into account the change of scenarios, that is, the change of context, along with the change of thinking and cognition. Mencius observed the development and change of things around, and the language usages dialectically; at the same time, he normalized the cognition of the right and wrong aspects of things in the way of thinking, constantly modified his beliefs, so as to make it more in line with the handling of complex situations in reality. On the basis of adhering to the feudal etiquette, flexible grasp of the change of the situation was not only reflected in the change of thinking and understanding, but in the use of language in the process of argumentation and the elaboration of ideas and propositions, as well as both sides' runs in the process of argumentation.

Refusing to run only in one groove and abiding by the principle and flexibility simultaneously is an important embodiment of Mencius' dialectics, which is the methodology of Mencius' argumentation, the inheritance and even development of Confucius' Doctrine of the mean thought, and also the theoretical foundation of Mencius' argumentative talent. Reflected in the dialectics, Mencius handled the difficulty proposed by Chunyu Kun, considered the changes of the contextual scene, analyzed the specific problems, and put forward his own position in view of the difficult problems put forward by the other party, in order to change the standpoint of the other party and reach the shared agreement of the starting points of the argumentation. Based on the premises or starting points of the argument agreed by both sides, through critical exchanges, that is, both parties refuted each other's views, defended and proved their own views, circulating until the final settlement of differences of opinion, which makes the understanding or judgment of the things or opinions of both sides tend to be consistent. In other words, abiding by the principle and flexibility is the concrete embodiment of the philosophical thought of "dialectics" in Mencius' argumentative practice, which also laid a solid foundation for Mencius to further elaborate his benevolent policy, and then a new round of argumentation also opened.

\section{RHETORICAL EFFECTIVENESS}

Rhetoric is a kind of language activity which aims at using language processing technology skillfully to improve expressive power of the language, and enhancing the infectious force and persuasive effect of argumentation. In the process of arguing for his benevolent policy, Mencius masterly employed the more popular rhetorical methods at that time, among which, the most commonly used rhetorical device by Mencius is metaphor. Rhetorical devices such as rhetorical questions and citation were also often used. Mencius said, "if you are not good at rhetoric, you cannot succeed," which is intended to emphasize the important part that rhetoric plays in argumentation. Van Eemeren et al added rhetorical dimension to the standard theory of Pragma-Dialectics, and then, in the process of argumentation, both sides carried out a series of strategic manipulative steps, so that on the basis of following the dialectical reasonableness, authors or speakers would make the arguments develop in a more favorable direction towards themselves and eventually achieve the rhetorical effectiveness.

Metaphor can be seen everywhere in Mencius' argumentation, and "using metaphor ingeniously" is one of the characteristics of its language expression. The so-called metaphor refers to a rhetorical technique in which A (class) thing and B (class) thing are mentioned in the process of language expression, between which there are some similar attributes, and by virtue of the attributes of $\mathrm{B}$ (class) thing to express the attributes of A (class) thing. In the argumentation of Mencius, we often use concrete things to express abstract things, simple examples to profound truth, and so on, "The words are simple but the meaning is profound" is in line with the personality characteristics of Mencius' being good at argumentation.

During the reign of King Xuan of Qi, the internal affairs were not repaired, and the people lived in poverty, "I can't afford to raise my parents, my wife and children! People in the age of enjoyment (after about 40 years) still work hard, and there are occasional disasters"( Mencius- KingHui of Liang (partone) ).However, King Xuan of Qi blindly wanted to promote hegemony, "wanted to expand the territory, so that the State of Qin and Chu paied homage to the Central Plains, appeased 
the ethnic minorities from all sides."So Mencius gave King Xuano f Qi a vivid metaphor, pointing out that his desire for hegemony is only a kind of unreachable delusion:

According to what you are doing now, wanting to realize such a great desire is like climbing up a tree to catch a fish (Mencius KingHui of Liang (part one)). ${ }^{9}$

In the passage above, "to pursue such an ideal" is anoumenon, and "climbing a tree to catchfish" is a vehicle. The result of "to pursue such an ideal" can be replied via "climbing a tree and catching fish. Obviously, "to pursue such an ideal" is a kind of foolish behavior without effort, so it is conceivable that King Xuan of Qi's "climbing a tree to catchfish" can only be a delusion which cannot be realized.

The very metaphor of Mencius is ingeniously conceived. To use a major political phenomenon as annoumenon, i.e., to achieve the ambition of dominating the world; to use the small things in daily life as a metaphor, i.e., to climb to the tree to catch fish. It is difficult to answer political questions such as whether KingXuan of Qi can realize his overbearing political aspirations, but it is self-evident to answer questions such as climbing trees to catch fish in daily life. Because of the fact that taking such small things in life as the inevitable failure of catching fish from the tree as a metaphor is analogous to the implementation of such a political event as hegemonism being bound to fail, King Xuan of Qi immediately understood the essence of Mencius, which paved the way for Mencius to persuade King Xuan of Qi to carry out the political ideal of benevolence. And that's what happened.

\section{The Dao of Mencius' Argumentation}

Mencius is good at argumentation and is a veritable language master. He opposes hegemony and pursues kingship. Moreover, in the process of arguing with princes, disciples and opponents, he has developed his own unique way of argumentation. That is to say, on the premise of abiding by logical rationality, strategic manipulation has been successfully implemented, and a delicate balance has been reached between dialectical reasonableness and rhetorical validity. Take the following paragraph of Mencius and his disciple Chen Zhen's argumentation on "acceptance" and "non-acceptance" as an example:

Chen Zhen asked, "in the past, when the king of Qi gave you a hundred pounds of gold, you did not accept it. When you arrived in the State of Song, the king gave you seventy, but you accepted it. In Xue, the king of Xue gave you fifty, and once more you accepted it. If the former non-acceptance is correct, then the latter acceptance is wrong; if the subsequent acceptance is correct, then the former non-acceptance is wrong. Teacher, you must have made a mistake once. "

Mencius said, "it's all right. When I was in the State of Song, I was ready to travel, and I should send some entanglement to those who traveled far away. So the Song King said, 'send some entanglement.' Why don't I accept it? When I was in Xue, I heard that there was danger on the road and needed to be on guard. Xue Jun said: 'I heard you need to be on guard, so send me some money to buy weapons.' How could I not accept it? As for the State of Qi, there is no reason. There is no reason to give me some money, which is tantamount to buying me off with money. How can you use money to buy a gentleman?"

As mentioned in Section 2, in the aspect of dialectical reasonableness, van Eemeren at al constructs a critical discussion model which is composed of four stages: the confrontation stage, the opening stage, the argumentation stage and the conclusion stage ${ }^{10}$.Return to the debate in terms of Mencius and disciple Chen Zhen on the "accept" and "do not accept". Mencius was challenged by Chen Zhen why Mencius did not accept it in the State of Qi, but in the State of Song and Xue he did. At this point, he had differences of opinion with Mencius and opened the confrontation stage. As Qi, Song and Xue are all familiar countries, and the meanings of "accept" and "non-accept" are agreed by both sides, which can be used as the starting points of the argumentation. After receiving the doubt from Chen Zhen, Mencius dialectically analyzed the different situations of the development of things, and used the strategy of tit for tat to construct anti-dilemma reasoning, which successfully broke the dilemma set by the other party. As a result, the argumentation stage is completed. In the conclusion stage, in the

\footnotetext{
${ }^{9}$ Yang Bojun. Mencius Translated Notes. Beijing: Zhonghua Book Company, 2010, p. 18.

${ }^{10}$ Greco S, van Eemeren F.H. and Henkemans A F S: Argumentation: Analysis and Evaluation,2nd Edition[M].New York and London: Routledge Taylor and Francis Group, 2017,pp.21-23.
} 
face of Mencius' two questions, "How could I not accept it?" "How can you use money to buy a gentleman?"Obviously, Chen Zhen was also caught in the dilemma set by Mencius and had to accept that all Mencius said was "all right".

In the aspect of rhetorical effectiveness, Mencius often grasps the other party tightly with various forms of questions, so that the other party unknowingly develops in the opposite direction of denying himself. "seducing questions" is one of the typical rhetorical strategies of Mencius. "seducing questions" is not to ask questions out of doubt, but to have a clear purpose of argumentation, that is, one side wants to make the other side think about one side's own proposition positively, make full use of status quo to induce the other side to give up his own proposition and accept one side's proposition instead, so one side asks questions to the other side intentionally. The argumentative technique of "seducing questions" is often used by both parties of the argumentation. Before seducing questions, one should be able to anticipate the response(s) from the other party. One side is often confident and more often than not ask questions to the other side continuously, which has the rhetorical effect of being good at giving systematic guidance, carrying the audience away, and letting the enemy enter the trap set by himself, together with a strong appeal and irrefutable persuasion. In the case of Mencius and his disciple Chen Zhen's arguing on "acceptance" and "non-acceptance", facing the dilemma put forward by Chen Zhen, being calm and quiet and actively proceeding from the premises from the other party's argumentation, Mencius did not stick to stereotypes; and viewed the development and changes of things dialectically; and was flexible and not stubborn while adhering to principles; and specific problems should be analyzed; and used the psychological tactics of "knowing words" to argue dialectically and drew the opposite conclusion of the argumentation so as to successfully break the dilemma put forward by the other side. More importantly, Mencius asked, "How could I not accept it?" "How can you use money to buy a gentleman? ", and adopted the strategy of not being stubborn while adhering to principles, inducing questions step by step, and on the basis of analyzing the different conditions of "acceptance" and "non-acceptance", methodically and magnificently, making the other side of the argumentation be struck dumb, and on the basis of accepting one side's premise, the other side unwittingly accepted one side's standpoint which was contrary to that of the other party. Mencius' skillful command of language shows his excellent argumentative skills.

As for rhetorical effectiveness, what must be mentioned here is the dilemma posed by Mencius and Chen Zhen, respectively. In the above argumentation between Mencius and Chen Zhen, Chen Zhen first proposed the following dilemma: If it was right not to accept a gift the day before, it is wrong to accept it today; if it is right to accept a gift today, it was wrong not to accept it the day before. Either it was right not to accept gifts the day before, or it is right to accept gifts today. Therefore, either it is wrong to accept gifts today, or it was wrong not to accept gifts the day before. At this moment, Mencius was caught in a dilemma. However, Mencius believed that things were developing and changing, and when things occurred, the time, place and conditions of development changed, then the judgment of the right and wrong of a thing should also change accordingly: The reason for accepting the state of Song is that it is a long way to go, and it is necessary to travel by means of transportation. The reason for accepting the state of Xue is that he is worried that if he meets bad people on the road, he needs to spend money to buy weapons for self-defense. The reason for not accepting the state of Qi is that there is no reason to accept gifts from others within the State of Qi, so they do not accept them. Mencius used the method of "attacking your shield with your spear", and with his superb wisdom, Mencius successfully broke the dilemma put forward by Chen Zhen with an anti-dilemma, which is constructed as follows: If it is right not to accept a gift the day before, it is right to accept it today; if it is right to accept a gift today, it is also right not to accept it the day before. Either it is right not to accept gifts the day before, or it is right to accept gifts today. So, either it's right to accept a gift today, or it's right not to accept it the day before. Mencius affirmed the antecedents of the two hypothetical premises in the dilemma put forward by his disciple Chen Zhen, but denied the consequents of the two premises in the corresponding dilemma, and concluded that "perhaps it is right to accept gifts today" or "it was right not to accept gifts the day before". The anti-dilemma constructed should be correct as far as possible, but from the effect of refuting the opponent in argumentation, as long as it can achieve the effect of "Deal with a man as he deals with you" ${ }^{11}$. It is not only a special refutation method, but also a special rhetorical device, which can form a strong language potential, enhance the

${ }^{11}$ Jiang Quanji, Chi Weidong. Logic (third Edition) [M]. Beijing: higher Education Press, 2007,p. 152. 
persuasive or combat effectiveness of language expression, and make the other party impeccable. Although Mencius was not familiar with the logical theory of dilemma, Mencius rebuked the dilemma put forward by Chen Zhen and discussed the object of argument according to the law of exclusion and the law of non-contradiction, which is completely consistent with the validity rules of logical reasoning, highlighting the logical rationality, so that he was always in an invincible position in the arguing.

In addition, Mencius highlighted the obvious dialectical thought ${ }^{12}$ in the debate with his disciple Chen Zhen. In the argumentation above, from the point of view of "knowing words" and "knowing categories", Mencius has no absolute difference in examining the right and wrong of "acceptance" and "non-acceptance", and the criterion for determining right and wrong depends on the actual situation in the local area at that time. In the concrete analysis of the specific problems, on the basis of not violating the objective reality, cognitive judgment of right and wrong is placed under the background of dialectics, and the dialectical consciousness and attitude are integrated into the judgment of right and wrong. Dialectical thinking is used to standardize their own cognition of right and wrong about the development and change process of things, making agents constantly revise their own judgment of right and wrong about objects. This dialectical cognition on the judgment of right and wrong about objects reflects that agents respect objectivity and give full play to subjective initiative altogether. Reflected in the argumentation, that is, to clarify and explain the key concepts in the process of arguing, so as to enable both sides of the debate to reach consensus and acceptance on the substantive or cognitive starting points before further argumentation, which is not useless for the argumentation to proceed smoothly

\section{CONCLUSION}

On the whole, communication and argumentation without logical rationality won't succeed. The dialectical dimension is permeated with the logical dimension, otherwise the dialectical dimension lacks the rational foundation of logic, and argumentation will commit many fallacies and even become sophism. The rhetorical dimension is designed to achieve the effectiveness of convincing the target audience, and if we excessively pursue argumentative means and presentational devices, it may backfire and lead to the so-called derailment of strategic maneuvering - fallacy, which is not allowed in any speech activity ${ }^{13}$.It cannot be said that Mencius' argumentation practice has no defects, but his argumentation always permeates two aspects: dialectical reasonableness and rhetorical effectiveness, and achieves a balance in some aspects. In other words, Mencius reached a balance among dialectical reasonableness and rhetorical effectiveness in the process of carrying out the arguing for benevolence. Mencius' "being argumentative" is the result of history and times, whereas his "being good at argumentation" is the result of his own language practice and knowledge accumulation. Mencius' argumentative methods and skills are the knowledge criterion of traditional Chinese cultures. In the era with contention of a hundred schools, the Dao of his argumentation, using logical reasoning, serves his own needs of political argumentation to carry out the theory of "benevolent governance", at the same time, ultimately serves the sense of social responsibility to make the people live and work in peace and contentment.

Meanwhile, Mencius' thought of abiding by the principle and flexibility simultaneously has somewhat enlightening significance for handling civil cases in the legal argument. This is because, although the law is sacred and solemn, the written legal provisions do not apply to all legal cases. Arbitration and mediation can sometimes properly deal with civil cases, at the same time, the adjudicator is also given a certain discretion, which is the concrete embodiment of the thought of abiding by the principle and

\footnotetext{
${ }^{12}$ Zhang Xiaomang. The Art of argumentation in Ancient China [M]. Taiyuan: Shanxi people's Publishing House, 2002, pp.150-151.

${ }^{13}$ Strategic maneuvering was first proposed by Frans van Eemeren. In his opinion, in order to effectively persuade the target audience, the rhetorical dimension is added to the critical discussion model of the standard theory of argumentation, and the selection of potential topics, audience demands and presentational devices are carefully designed to make the outcome of argumentation develop in favor of the arguer himself. Of course, if the pursuit of rhetorical effectiveness is excessive and the boundary of logical rationality is crossed, in a vivid metaphor, when the train is in the process of running, the wheels leave the track, causing traffic accidents, causing passengers to be injured or damaged by the railway. In this way, it is vividly metaphorical that the strategic maneuvering has been derailed, and the very argumentative move is a fallacy. Seevan Eemeren F.H. Strategic maneuvering in argumentative discourse: extending the pragma-dialectical theory of argumentation [M]. John Benjamins Publishing Company, Amsterdama/ Philadelphia:John Benjamins Publishing Company, 2010, p.41.
} 
flexibility simultaneously. Therefore, some of Mencius' argumentation methods have certain significance for reference to perfect the legal argumentation theory. Its practical significance lies in that, on the contrary, for individuals, in today's fierce social competition, argumentation is one of a person's core competitiveness; For the whole country and society, the discussion of public issues in contemporary society is a necessary means to build a harmonious society. Both can learn from Mencius' argumentation skills and persuasion means, so as to enhance individual social competitiveness and promote social progress and development.

Through a series of argumentative steps by strategic maneuvering, a rational balance ${ }^{14}$ has been found between dialectical reasonableness and rhetorical effectiveness, which sounds the historical horn of social change. The study of Mencius' argumentative method not only has theoretical significance, but has certain practical significance. Its theoretical significance lies in that Mencius' argumentative skills are the same as Aristotle's argumentation theory ${ }^{15}$ and the extended pragmatic argumentation theory in contemporary argumentation theory, and the three can be compared, and integrated so as to complement each other. The future work is to make up for shortcomings of the three, try to explore the advantages among them, and then integrate these merits into one argumentation theory.

\section{REFERENCES}

[1] Van Eemeren F.H., Garssen B., Krabbe E.C.W., et al. Handbook of Argumentation Theory[M]. Berlin:Springer Netherlands.

[2] Van Eemeren F.H. Strategic maneuvering in argumentative discourse: extending the pragma-dialectical theory of argumentation [M]. Amsterdama/Philadelphia :John Benjamins Publishing Company.

[3] XiongMinghui. Logical Analysis of Natural Language Argumentation and Evaluation. Philosophical Studies.

[4] Wu Peng, XiongMinghui. Strategic Maneuvering: a Rhetorical Extension of Pragma-Dialectics. Journal of Fujian normal University (Philosophy and Social Sciences Edition).

[5] Van Eemeren F.H., R. Grootendorst, A. F. S. Henkemans: Argumentation: Analysis, Evaluation, Presentation [M]. Mahwah: Lawrence Erlbaum Associates.

[6] Van Eemeren F. H. Argumentation Theory: A Pragma-Dialectical Perspective[M]. Springer Netherlands.

[7] Yang Bojun. Mencius Translated Notes. Beijing: Zhonghua Book Company.

[8] Greco S, van Eemeren F.H. and Henkemans A F S: Argumentation: Analysis and Evaluation,2nd Edition[M].New York and London: Routledge Taylor and Francis Group.

[9] Jiang Quanji, Chi Weidong. Logic (third Edition) [M]. Beijing: higher Education Press.

[10] Zhang Xiaomang. The Art of argumentation in Ancient China [M]. Taiyuan: Shanxi people's Publishing House.

\section{AUTHORS' BIOGRAPHY}

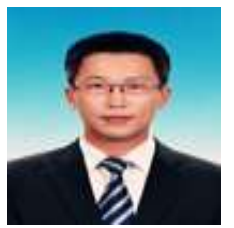

Yang Zhaofu, who is a PhD Candidate. His research fields are argumentation theory, critical thinking as well as game theory and so on. He currently is learning in School of Philosophy, Beijing Normal University, China.

Citation: Yang Zhaofu. "A Preliminary Study on the Method of Mencius 'Argumentation - From the Perspective of Pragma-Dialectics". International Journal of Humanities Social Sciences and Education (IJHSSE), vol. 6, no.11, 2019, pp. 31-38. doi: http://dx.doi.org/10.20431/2349-0381.0611005.

Copyright: (C) 2019 Authors. This is an open-access article distributed under the terms of the Creative Commons Attribution License, which permits unrestricted use, distribution, and reproduction in any medium, provided the original author and source are credited.

\footnotetext{
${ }^{14}$ Xiong M, Yan L. Mencius's Strategies of Political Argumentation [J]. Argumentation, 2018(3):1-25.

${ }^{15}$ Aristotle's argumentation theory consists of three fields: analytical (analytic), argumentative (dialectic) and rhetorical (rhetoric), which correspond to the current three fields of logic, argumentation and rhetoric, respectively. On the basis of argumentation, the extended pragmatic argumentation theory adds the rhetorical dimension and integrates the three fields of logic, argumentation and rhetoric. vanEemeren F.H. In What Sense Do Modern Argumentation Theories Relate to Aristotle? The Case of Pragma-Dialectics[J]. Argumentation, 2013, 27(1):49-70.
} 